\section{Responding to Richard: Celebrity and (mis)representation of science}

Public Understanding of Science

(C) The Author(s) 2016

Reprints and permissions: sagepub.co.uk/journalsPermissions.nav DOI: I0.1 I77/096366251667350। pus.sagepub.com

(\$SAGE

\author{
David R. Johnson
}

University of Nevada, Reno, USA

\author{
Elaine Howard Ecklund, Di Di \\ and Kirstin R.W. Matthews \\ Rice University, USA
}

\begin{abstract}
Drawing on 48 in-depth interviews conducted with biologists and physicists at universities in the United Kingdom, this study examines scientists' perceptions of the role celebrity scientists play in socially contentious public debates. We examine Richard Dawkins' involvement in public debates related to the relationship between science and religion as a case to analyze scientists' perceptions of the role celebrity scientists play in the public sphere and the implications of celebrity science for the practice of science communication. Findings show that Dawkins' proponents view the celebrity scientist as a provocateur who asserts the cultural authority of science in the public sphere. Critics, who include both religious and nonreligious scientists, argue that Dawkins misrepresents science and scientists and reject his approach to public engagement. Scientists emphasize promotion of science over the scientist, diplomacy over derision, and dialogue over ideological extremism.
\end{abstract}

\title{
Keywords
}

popularization of science, science and religion, science communication

\section{Introduction}

Some scientists take on a public role that entails broad communication with non-scientific audiences, but exceedingly few achieve celebrity status for doing so. Yet, scientists like Richard Dawkins, Neil deGrasse Tyson, Stephen Hawking, Jane Goodall, and Carl Sagan represent a phenomenon in science that moves beyond simply communicating science well, to achieving immense personal visibility with the broader public (Goodell, 1977). Such scientists have achieved status as celebrities who link science and popular culture. Although minimal in number, these scientists are important because their prominence in media and economic markets allows them to wield powerful influence over public dialogue related to issues at the intersection of science and society and the representation of science in the public sphere (Goodell, 1985). Given this influence, a growing area of research on public communication of science focuses on "celebrity scientists" or 
scientists especially prominent within popular culture who actively cultivate a public presence (Elsdon-Baker, 2009; Fahy, 2015; Fahy and Lewenstein, 2014; Giberson and Artigas, 2007; Scheitle and Ecklund, 2015).

Celebrity scientists are also important because they see themselves and others see them as actual representatives of science as a social institution, having a much broader symbolic significance than their individual identities. Their actions link the broader scientific community to a common assessment, raising the question of whether celebrity scientists are ideal representatives of their colleagues. Giberson and Artigas (2007), for example, suggest that celebrity scientists" "portrayals of science may be skewed or even distorted and science might be misunderstood" (p. 7). Focusing on Dawkins' representation of mechanisms of evolution, Elsdon-Baker (2009: 233) asserts that Dawkins' argument that natural selection acts on genes alone is not necessarily representative of all evolutionary biologists. Yet we know very little about how well he speaks for biologists - or scientists more generally - in his representation of science and religion debates. Indeed, given that Dawkins' public pronouncements on religion are often unrelated to biological mechanisms, he can be seen not just as a representative of bioscience, but physical and natural sciences more generally.

Here, we draw upon interview data from the British subset of the Religion among Scientists in International Context study (RASIC), a mixed-methods study that includes a survey and 609 indepth interviews with biologists and physicists in France, Hong Kong, India, Italy, Taiwan, Turkey, the United States, and the United Kingdom (Ecklund et al., 2016). RASIC is a sociological examination of how scientists think about religion and their perception of the science-faith interface, in addition to other themes such as ethics. We delimit our focus to discussions about science and religion with 137 British scientists, analyzing a subset of 48 interviews in which scientists specifically discussed Dawkins. The United Kingdom should not be viewed as the model case or norm in understanding popularization of science (Daum, 2009). Nevertheless, it would appear that there is a distinct relationship between Dawkins and his colleagues in the United Kingdom because scientists in other countries we studied rarely brought him up.

Although the empirical context is scientists' perceptions of Dawkins, Dawkins is simply an analytic case through which the role of the celebrity scientist in socially contentious debates can be analyzed. This study is important because it is the first of its kind to empirically assess whether scientists perceive celebrity scientists as ideal representatives of science. The study of Dawkins' role in debates about the relationship between science and religion in the United Kingdom, his home nation, is an interesting case as well; while he argues that there is an intrinsic conflict between science and religion, many scientists - even most nonreligious scientists - do not perceive a conflict between being religious and being a scientist in the abstract sense (Ecklund, 2010; Ecklund et al., 2016; Ecklund and Park, 2009). Analyzing how scientists perceive Dawkins thus represents an important case from which recommendations can be made for improving dialogue in debates related to conflict between science and social values.

Findings show that Dawkins' proponents view the celebrity scientist as having an important role as a provocateur, who asserts the cultural authority of science in the public sphere. Critics, who include both religious and nonreligious scientists, construct the celebrity scientist as a diplomat of science whose engagement should anticipate and understand the perspectives of public audiences. His critics perceive Dawkins as misrepresenting science and scientists. And his engagement style is rejected on the grounds that it promotes the scientist over science, derision over diplomacy, and ideological extremism over dialogue.

\section{Celebrities in science}

An individual's knowledge of science rarely shapes attitudes toward or support for science (Bauer et al., 2007). Instead, affective factors, such as whether science communicators are perceived as 
sharing one's values (Kahan et al., 2011), views about science in society (Brossard and Nisbet, 2007), or whether communicators are seen as fair (McComas and Besley, 2011), heavily shape public perceptions of science. Science, technology, and society (STS) scholars increasingly examine deficits of technical experts, such as how scientists' conceptions of the public frame and even potentially misguide the communication efforts of scientific institutions (Bauer et al., 2007). A broad array of actors engage with the public, but scientists have the most visibility in public communication roles (cf. Ecklund et al., 2012; Johnson et al., 2014). While popularization can lead to heightened visibility, it rarely results in the achievement of celebrity status.

Fahy and Lewenstein (2014) assert that the notion of the celebrity scientist emerged primarily during the last century. But within evolutionary biology alone, one can see that the celebrity scientist is not a creation of the recent past. Although Charles Darwin had a reputation for privacy, he received fan mail, signed autographs, collected poems and songs composed about him, and received numerous visits to his home, visits historians view as the Victorian equivalent of a celebrity interview (Browne, 2003). Dawkins is also following a precedent set by Ernst Haeckel, whose Natural History of Creation - the "gospel of evolutionary theory"-was translated into 25 languages by 1909 (Daum, 2009).

Yet, historical and contemporary modes of celebrity are distinct. Darwin's celebrity status was unavoidable (Browne, 2003), rather than one actively cultivated through strategic self-promotion. Haeckel and Dawkins are similar in their vociferousness and opposition to religion, but the contexts of their engagement could not be more different. Haeckel's popularization took place in the context of the mid-nineteenth century nascent secularism of Germany (Weir, 2014), whereas Dawkins' engagement takes place in the context of a well-established and highly secular UK public (Voas and Crockett, 2005). Technology has also radically changed public engagement by reducing spatial and temporal barriers to communication, which limited celebrity scientists in earlier periods.

An important gap in this area of research concerns the implications of celebrity science for scientific practice itself and the interface between science and the public (Fahy and Lewenstein, 2014). An important step in addressing this gap is to assess celebrity scientists' roles as stakeholders in "meta-discourses" about the science-society relationship, such as conversations about the relationship between science and social values (Peters, 2014). This is important because scientists who assume public roles in policy issues do not deliver expertise that is value free (Mazur, 1985). When celebrity scientists act as stakeholders in broad conversations about science and society, however, the reach of their influence through media and engagement may be taken by the public as representative of what science "is" - even when the broader scientific community is characterized by differing stances on issues like the role of science in society or aspects of scientific practice. Thus, one step toward understanding the implications of celebrity science for public communication of science entails examining scientists' own perceptions of celebrity scientists, the extent to which they support celebrities as representatives of the scientific community, and the possible implications of these views for how the community interacts with the public. We offer insight into this problem by examining specifically how British scientists respond to Dawkins, evaluating the case of Richard Dawkins as a stakeholder in the enduring public debate over the relationship between science and religion.

The relationship between science and religion has been a recurring basis of public discourse. In particular, there has been a resurgence and global spread of religiously based anti-evolutionism since the 1960s (Numbers, 2006), which has generated public debate around the world. For example, in the United States, politicians in 26 states introduced 110 "anti-evolution" bills between 2000 and 2012 that sought to alter how evolution is taught in public schools (Johnson et al., 2016), while vocal groups of evangelical Christians have opposed human embryonic stem cell research (Ho et al., 2008). In Europe, high-ranking government officials in Italy, Germany, and Poland sparked 
separate cases of backlash in response to controversial statements about evolution, while a vote to denounce the teaching of creationism alongside evolution passed only after fierce opposition within the Council of Europe (Curry, 2009). Similar discourse over science and religion can be found in Asian countries (Cyranoski, 2009; Jayaraman, 2001).

At the core of such debates are two types of conflict: epistemological, where different methods of truth claims lead to different conclusions about the origins of the natural world, and moral, in which there is religious opposition to the research agendas of scientists on issues such as embryonic stem cell research (Evans, 2011). Most discourse - as seen above - centers on epistemic conflict related to evolution, but conflict narratives are not necessarily consistent with empirical evidence. A 2009 British Council poll in 10 countries finds that perception of conflict between evolutionary worldviews and belief in God is a minority view (Elsdon-Baker, 2015), a finding consistent with research among the US public (Baker, 2012), college students (Scheitle, 2011), and academic scientists (Ecklund, 2010). The perception of compatibility often arises from the independence perspective, captured in Stephen Jay Gould's (1998) notion of "nonoverlapping magisteria," which asserts that science and religion are domains of autonomous authority. According to this view, science addresses questions related to the empirical natural world, while religion addresses questions of meaning and ethical values.

One way in which some celebrity scientists construct their public image is using religion as a reference point to express their anti-religious (Dawkins, 2006) or pro-religious viewpoint (Collins, 2006). In The Selfish Gene, Dawkins ([1976] 1989) says, "Religion is capable of driving people to such dangerous folly that the faith seems to me to qualify as a kind of mental illness" (pp. 330331). Dawkins (1986) further claims that he wants to persuade the public, "not just that the Darwinian world-view happens to be true, but that it is the only known theory that could, in principle, solve the mystery of our existence" (p. xiv), elsewhere arguing that religion is not relevant to the mystery of existence.

Most people in the public establish a connection between atheism and science, believing that atheism and science mutually support each other (Scheitle and Ecklund, 2015). In Western nations, scientists are more likely to be nonreligious and less likely than the general public to believe in God (Ecklund, 2010). For example, in a study of US scientists at elite universities, Ecklund and Scheitle (2007) find that $34 \%$ and $31 \%$ of scientists identify as atheists and agnostics, respectively, while only $25 \%$ indicate belief in a personal god. In the United Kingdom, only $27 \%$ of scientists and $47 \%$ of the general public identify as slightly, moderately, or very religious (Ecklund et al., 2016).

What remains unclear is the extent to which Dawkins' approach to articulating his views is supported by his peers in the scientific community. In all, $35 \%$ of UK scientists view the relationship between science and religion as one of conflict and are on the side of science (Ecklund et al., 2016). Yet, scientists who embrace this view, and still others, may disagree with the means by which Dawkins articulates his atheist views to the public. Another important gap, according to Fahy and Lewenstein (2014), is what implications the views of celebrity scientists have for how other scientists practice or view science communication. Here, we treat scientists' perceptions of Dawkins as a case to understand the role of the celebrity scientist in socially contentious issues in the public sphere and the ways in which celebrity scientists shape scientists' attitudes toward public engagement.

\section{Data and method}

The data for this analysis are drawn from the UK subset of the RASIC, a mixed-methods study on the social context of science in India, Italy, France, Hong Kong, Taiwan, Turkey, the United Kingdom, and the United States (Ecklund et al., 2016). The goal of the study is to understand how 
Table I. Study sample characteristics (in percentage terms).

\begin{tabular}{lll}
\hline & $\begin{array}{l}\text { UK interview } \\
\text { sample }(N=137)\end{array}$ & $\begin{array}{l}\text { UK analytic } \\
\text { sample }(N=48)\end{array}$ \\
\hline Female & 18.8 & 40.1 \\
Biologists & 54.2 & 55.5 \\
Elite & 81.3 & 72.3 \\
Graduate students & 12.5 & 19.7 \\
Junior to senior appointments & 37.5 & 47.4 \\
Full professors & 50.0 & 32.8 \\
\hline
\end{tabular}

scientists think about religion, the science-faith interface, and other aspects of their careers. The qualitative component of the study includes 609 in-depth interviews with biologists and physicists. Although they cannot be generalized to all of science, biology and physics are two core science disciplines that face different religious issues through their explanations of the origins of humanity and the universe, respectively.

We identified universities and research institutes in each country through an analysis of 10 years of publication data from the Web of Science, an online database with citation information for more than 12,000 scientific journals. After randomly selecting universities from compiled lists, we developed rosters of all scientists affiliated with departments of physics and biological sciences, and then randomly selected scientists who we then sent invitations to participate in the study. The majority of the interviews were conducted in scientists' offices by the co-authors and other researchers, with the remaining portion conducted via Skype or telephone. The interviews were semi-structured, with questions related to different aspects of the social contexts of science, including religion, ethics, and work and family, but they did not include questions about celebrity scientists or popularization of science.

Here, we focus on 48 of the 137 participants from the United Kingdom who, when discussing religion, brought up Richard Dawkins. Of these 48 scientists, 35 scientists brought up Dawkins without prompting from the interviewer, while 13 mentioned Dawkins when asked about influences on their perception of the science-faith interface. In Table 1, we provide an overview of the demographic characteristics of the study sample. UK scientists who brought Dawkins up, like the broader sample of interview participants in this region, tend to be evenly divided by discipline and located primarily at elite universities. That both biologists and physicists invoked Dawkins when discussing science and religion indicates that Dawkins is not simply seen as a representative of the biosciences in his public presentation of the relationship between science and religion, but as representing science in the public sphere. The scientists are also somewhat similarly distributed in terms of career stage, with slightly higher proportions of graduate students and scientists in junior to senior appointments (postdocs, assistant professors, lecturers, readers) in the analytic sample. Scientists in the highest rank of professor, however, were much less likely to reference Dawkins. Compared to the overall interview sample, female scientists were much more likely to mention Dawkins in their interviews.

In total, 23 scientists from contexts outside of the United Kingdom also mentioned Dawkins. In contrast to British scientists, who often spoke in relatively deep detail about Dawkins, scientists outside of the United Kingdom had relatively little to say about him, other than having familiarity with his books. Additionally, none of the countries outside of the United Kingdom had a large enough number of scientists to draw any conclusions about country- or region-specific patterns. We therefore do not include these scientists in our analysis, but speculate later about whether there is anything specifically "British" about the Dawkins case. 
Given that one-third of the 137 scientists who participated in interviews discussed Dawkins in the context of religion, we began coding for content related to Dawkins when examining factors influencing scientists' views of the relationship between science and religion. We conducted a lineby-line open coding of the selected quotes (Strauss and Corbin, 1990) and initially categorized respondents' narratives according to supportive or critical views of Dawkins. We then categorized each narrative according to the rationale underlying a given scientists' support or critique of Dawkins' engagement with the public. Subsequent analysis examined possible difference in perspective according to gender, discipline, and religious identities, with only religious identity factoring prominently into how proponents of Dawkins view the role of the celebrity scientist in public debates related to conflict between science and social values.

\section{Findings}

\section{The celebrity scientist as preaching to the choir and provocateur}

In all, 10 of the 48 UK scientists who discussed Dawkins champion his ideas and approach and are proponents of his argument regarding the tensions between science and religion. Unsurprisingly, most of these scientists share Dawkins' approach to religion, meaning that many self-identify as atheist, although some are agnostic (none in this group are religious). And all but three are biologists, which could be a reflection of the fact that evolution is one of the most frequent sources of controversy in public discourse. Two narratives define this group. One, related to the personal impact that Dawkins has had on study participants, emphasizes ideological affirmation. For example, a nonreligious biologist ${ }^{1}$ who, when asked about influences on her view of the relationship between science and religion, responds,

There have been many books I've been influenced by one way or the other, even when I was religious ... I have to say that a book that — it didn't make it—but it crystallized my atheism was The God Delusion by Richard Dawkins.

Discussing the same book, a nonreligious postdoctoral physicist ${ }^{2}$ similarly explains,

I read a book on religion ... The God Delusion by Dawkins and then a few others, but, yeah, I mean, at the point in my life when I read them I was already ... an atheist so it's a bit of preaching to the choir.

The majority of the nonreligious scientists we interviewed were nonreligious before acquiring a scientific education, implying that among scientists, exposure to Dawkins affirms the opinion of audiences that already share his views. In the words of a nonreligious professor of biology who said she had read The God Delusion, "I'm already on [his] side."

A second narrative of the celebrity scientist is as provocateur; respondents portray Dawkins' public engagement as having more of an impact than simply "preaching to the choir." By provocation, scientists emphasize the assertion of the cultural authority of science through agitation in the public sphere. A nonreligious professor of biology ${ }^{3}$ represents this theme and says of Dawkins:

He's probably a bit more reactionary than I would be, but I think he has quite an important place in society actually in prodding things.

According to this scientist, even if Dawkins is primarily affirming the view of like-minded scientists and members of the public, his aggressive mode of public engagement is important because it perpetuates and validates the authority of science in a highly visible manner. The scientist's 
emphasis on "reactionary" is indicative of a broader perception that Dawkins' approach is perhaps too aggressive. This implies a perceived risk of alienating some audiences, yet such scientists view this outcome as an acceptable cost of asserting the authority of science in the public sphere. Scientists embrace Dawkins as public provocateur even when they do not fully embrace the intellectual content of his argument. A nonreligious lecturer of biology, ${ }^{4}$ for example, who says "I wouldn't say that [his books are] always right, but they're certainly an interesting take ...," goes on to discuss one of Dawkins' books:

It sparked some interesting conversations actually ... which probably wouldn't have happened otherwise ... it was thought provoking definitely, which I think is always a good thing.

Provocation is celebrated by this scientist and others like her because even if one disagrees with the substance of Dawkins' arguments, his engagement is seen as provoking discussion among his audiences, allowing an exchange of ideas. Whether perceived as preaching to the choir or as a provocateur, Dawkins is supported by many nonreligious scientists who see a need to aggressively assert the cultural authority of science in the public sphere.

\section{Misrepresenting science}

Among the 48 UK scientists who talk about Dawkins, the majority of them (38 scientists) disagree with how he fills his role as a celebrity scientist. Surprisingly, this group comprises both religious and nonreligious scientists, with the nonreligious largely outnumbering the religious: 23 of the scientists who critique Dawkins are nonreligious while 15 identify as religious. The overarching assertion of his critics is that Dawkins misrepresents science and scientists.

One cluster of scientists in this group argues that Dawkins' public engagement misrepresents what science (as a process or method) can do. Representative of this pattern is a nonreligious professor of biology ${ }^{5}$ who brought up Dawkins when discussing how to emphasize the limitations of science to students, namely, what science can and cannot address:

Some people like Richard Dawkins ... He's a fundamental atheist. He feels compelled to take the evidence way beyond that which other scientists would regard as possible ... I want [students] to develop [science] in their own lives. And I think it's necessary to understand what science does address directly.

Similarly, a nonreligious graduate student in biology, ${ }^{6}$ who says he actively follows Dawkins and public debates related to science and religion, asserts that Dawkins "may be talking in ways which are bigger than science can answer." Thus, some scientists - independent of their religious views - do not view Dawkins as a good representative of the scientific community because they believe he conveys the wrong impression about the borders of scientific inquiry. Implied in this view is the independence perspective, which posits that science and religion do not overlap because they address fundamentally different questions. Although scientists differ in their view of where such borders rest, and may even view belief in a deity as irrational, they do not view questions related to the existence of deities or "the sacred" as within the scope of science.

The notion that Dawkins is a "fundamental atheist" reflects a second and more prevalent assertion that Dawkins publicly conveys an inaccurate impression of scientists. One sentiment, captured by the emphasis on fundamentalism, is that Dawkins - as a symbolic representative of the community_-gives the impression that scientists are dogmatic rather than open. Consider the account of a religious physicist, who works as a postdoctoral fellow ${ }^{7}$ and who expresses irritation with the kind of assertions fundamentalist religious groups make about science. This scientist states, 
You can understand someone like Richard Dawkins being particularly hacked off by it and retaliating, but ... people on both sides ... [are] overly dogmatic ... [and go] beyond perhaps what the state of the agenda is. The agenda of the scientist is to ask how, but it's not because I want to prove that God doesn't exist.

Here, we observe a tension between scientific norms and counter-norms. As these scientists argue, Dawkins' celebrity role gives the public impression that scientists practice organized dogmatism (Mitroff, 1974). Scientists who critique Dawkins for his dogmatism espouse adherence to organized skepticism (Merton, 1973) or the idea that scientists should continually doubt their own findings as well as those of others. In the words of a nonreligious reader in physics, ${ }^{8}$

He's much too strong about the way he denies religion ... As a scientist you've got to be very open, and I'm open to people's belief in religion ... I don't think we're in a position to deny anything unless it's something which is within the scope of science to deny ... I think as a scientist you should be open to it ... It doesn't end up encroaching for me because I think there's quite a space between the two.

Scientists are not saying there is a place for religious explanations within the sphere of scientific authority. The critique is that the vigor and tone of Dawkins' commentary on religion come off as "a polemic," "9 and as a result, scientists are portrayed very visibly as biased or as having agendas that are not objective. As a reader in physics ${ }^{10}$ explains it,

I mean I haven't read any of his recent books ... The impression I get from the newspaper reports ... I just kind of feel that ... he's kind of trying to be sort of a perfect, rational person somewhere but you know he's ... kind of portraying that that's how scientists kind of think, that's what scientists say and so on and that kind of does ... create the wrong impression.

Dawkins' atheism may be representative of a major segment of scientists in the United Kingdom, but his peers do not view him as a good representative of the scientific community because - in their view-he conveys the wrong impression about what science can do and the norms that scientists observe in their work.

\section{Perspectives on the practice of celebrity public engagement}

Beyond a consideration of whether Dawkins actually represents the scientific community in socially contentious issues, scientists' narratives about his public engagement also permit an examination of the relationship between celebrity science and the practice of science communication itself. Although 10 scientists characterized Dawkins' celebrity scientist role as a provocateur, an implicit vote of support for how he engages with the public, Dawkins' critics, in contrast, think his manner, rather than the content of his public commentary, does a disservice to the public understanding of science. Scientists - even those who find his work interesting and who share his identity as an atheist - assert that Dawkins is "doing a disservice to evolution," "11 "not a great sort of face of science ...,"12 and "not sure he's really helping the cause very much lately."13

Scientists view Dawkins more as an antagonist than as someone popularizing scientific knowledge or promoting support for the scientific endeavor. This is evident in the language scientists use to characterize his role in the public sphere. A religious lecturer in biology, ${ }^{14}$ for example, who states that "there is a lot of truth behind what [Dawkins] says" characterizes him as "stirring the pot." Such language connotes someone whose goal is to perpetuate tension (possibly for personal gain or enjoyment of confrontation) rather than a desire to persuade members of the public to alter their view of science or religion. A nonreligious graduate student in biology similarly views Dawkins as "rocking the boat," implying that Dawkins is causing trouble in an otherwise stable 
situation. In short, scientists are less critical of the intellectual content of Dawkins' public engagement than the form it takes.

Here, we analyze the key patterns among 38 scientists' critiques of how Dawkins communicates with the public, focusing on instances in which his behavior departs from scientists' expectations for how scientists engage the public engagement. In doing so, the analysis identifies scientists' perceptions of the appropriate and inappropriate role of the celebrity scientist and, more generally, acceptable and unacceptable practices of science communication.

One pattern is that scientists view Dawkins' approach to public engagement as focusing more attention on Dawkins himself than his arguments about the relationship between science and religion. Representative of this view is a religious postdoctoral physicist ${ }^{15}$ who when explaining that he has read Dawkins' work said, "I read The God Delusion ... but that just influenced the way I thought about Richard Dawkins." A related iteration of this theme emerges in how much discussion of Dawkins revolves around his identity. A nonreligious lecturer of biology, ${ }^{16}$ for example, referred to Dawkins as "Mr. Anti-God Europe," while other nonreligious biologists ${ }^{17}$ referred to him as "extremely arrogant" and "overly aggressive." Scientists believe there is a balance to be drawn between cultivating a public image and cultivating an understanding of science, without allowing the focus on the celebrity to supersede the focus on the science.

Scientists are also critical of Dawkins' motivations for public engagement. Consistent with the above characterizations of Dawkins as an antagonist, a nonreligious professor of biology ${ }^{18}$ states,

Well, he has gone on a crusade, basically ... I think that it's an easy target, and I think that he's rather insensitive and hectoring ... [A]lthough there is a lot of truth behind what he says ... he does it in a way that I think is deliberately designed to alienate religious people.

Scientists often acknowledge troubling aspects of the relationship between science and religion in the public sphere, but they nevertheless perceive Dawkins' approach as unproductive and alienating. Although critics rarely specify what the goals of public engagement in the science-religion discourse should be, their narratives imply a sense that communication with non-scientists should involve diplomacy rather than derision, even those non-scientists that our respondents disagree with.

The most prevalent critiques of Dawkins are related to the audiences he targets and how he approaches science communication. In total, 17 scientists, half of the Dawkins' critics in our analytic sample, assert that Dawkins' approach to public engagement is wrong because he operates at ideological extremes. Consider the account of a postdoctoral physicist ${ }^{19}$ who identifies as slightly religious:

He picked quite an easy target I would say ... If you say they have these extreme atheists and extreme radical religious persons, when they meet they will not be able to talk, they won't be able to understand ... But if you talk beliefs to people which are next to each other, probably they have more in common there ... [T] hey will be able to talk even though they have slightly different beliefs.

The basis of this view is that at attitudinal extremes - for example, positions such as militant atheism and religious fundamentalism - individuals are so deeply entrenched in a worldview that the public engagement only results in affirmation of one's standpoint. The implication is that celebrity engagement in the science-religion dialogue in the public sphere could be more productive if it targeted groups for whom new understandings of science or religion would be possible or points of agreement between the two. This perspective tends to be somewhat more prevalent among religious scientists, perhaps because they have a more nuanced perspective of the spectrum of religious beliefs that exist. For example, a religious professor of biology ${ }^{20}$ says that Dawkins is "as 
idiotic as the people who say God accounts for everything" because Dawkins targets fundamentalists. According to this view, operating at extremes undermines the credibility of Dawkins' message because he places himself on the same ideological plane as the groups and positions he critiques.

Dawkins' critics argue that a more productive approach to public engagement in the sciencereligion dialogue would be to better understand the public. Here, we encounter an image of the celebrity scientist as a science diplomat. As a nonreligious postdoctoral biologist ${ }^{21}$ explains, when discussing Dawkins,

I think you have to be very careful about stripping away people's beliefs without offering anything in return...If I talked to people, I talk to them [about] how I view things and how I understand things and I will ask questions of them...But just sort of shouting at people, "You're wrong and stupid" is not very productive.

Another religious postdoctoral biologist makes a similar comment:

If you're talking to somebody who is indoctrinated and has a hundred percent belief in their belief system, then you're getting absolutely nowhere by saying [God doesn't exist] ... [To] break them down, by far the easiest way is to actually study what their faith is.

Dawkins' approach departs from scientists' expectations for dialogue and social exchange in public engagement. This expectation holds under the two vastly different goals of changing individuals' religious beliefs and enhancing public understanding of the relationship between religion and science. In both cases, scientists see a need to attempt to understand one's audience and promote dialogue and different standpoints.

Only one scientist that we interviewed indicated that Dawkins' mode of public engagement influenced his own approach to communicating with the public. Like Dawkins, this biologist $\mathrm{t}^{22}$ is actively involved in science communication around science and religion public debates, although with much less visibility than Dawkins and no claim to celebrity status. While he shares Dawkins' sense of concern about the effects of religious belief on society and science, his public engagement is much different. Describing a book he wrote about evolution, he explains,

I actually tried to be as considerate as I could be to religious opinion. I decided partly because I thought it would sell more books, not to adopt the Dawkinesque viewpoint ... that religion is nonsense ... I just wanted to explore ... whether one could have religious beliefs and accept that evolution has happened.

Even if the stated goal was entirely based on selling his book, one nevertheless sees here a recognition that a broader audience and greater understanding could be reached through diplomacy and an attempt to understand the public.

\section{Discussion and conclusion}

This article examined scientists' perceptions of Richard Dawkins' involvement in public debates related to science and religion. Dawkins is treated as a case through which the role of the celebrity scientist in socially contentious debates in the public sphere can be analyzed, permitting us to respond to recent calls for research on the implications of celebrity science for science communication (Fahy and Lewenstein, 2014). To do so, we used a sample of 137 in-depth interviews with biologists and physicists at universities in the United Kingdom, focusing specifically on 48 scientists who brought up Richard Dawkins when discussing the relationship between science and religion. 
Celebrity scientists are important because their books, interviews, speeches, and other public engagements may be understood by the public as representative of what science "is" or indicative of agreement within the scientific community on a given issue. Whether or not the scientific community is characterized by differing stances on particular issues - such as the relationship between science and religion, and the role of science in society, or its consensus on scientific theories or practice such as the use of stem cells - highly visible scientists can easily be understood by the public as communicating the "official position" of the community (Scheitle and Ecklund, 2015).

Whether a celebrity scientist is viewed within the scientific community as speaking for the discipline is debatable. Drawing on an exhaustive history of evolutionary thought, Elsdon-Baker (2009) shows that it is generally accepted in certain scientific communities that Dawkins does not speak for all biologists. Whereas Elsdon-Baker (2009) focuses on Dawkins' representation of evolutionary biology, we build on her work by examining scientists' views of his representation of the debate surrounding science and religion. Some of the scientists we interviewed do see Dawkins as representative of their views, but even among atheists and agnostics, the modal pattern in our data is the perception that Dawkins misrepresents the types of questions science can answer and the norms that scientists observe. To be clear, none of the scientists we interviewed questioned Dawkins' identity or integrity as a scientist. The critique is aimed at his representation of science to the public. What makes this critique so ironic is the fact that Dawkins held a pre-eminent endowed chair in public understanding of science at Oxford from 1995 until 2008. It is also noteworthy that many of his critics are, like Dawkins, atheists.

And while some nonreligious scientists assert that Dawkins plays an important role as a provocateur who asserts the cultural authority of science, the more prevalent narrative among the scientists we studied is that Dawkins' engagement style is a disservice to the public understanding of science. The idea that Dawkins promotes himself more than science may be the least consequential engagement style, but being viewed as aggressive or arrogant by some constituencies is unlikely to advance appreciation for science. Having a derisive engagement style or operating at ideological extremes, by contrast, may even alienate constituencies that would otherwise be interested in consuming science.

These patterns are important because they identify scientists' normative expectations for public engagement of celebrity scientists in socially contentious debates. First, scientists assert that celebrity scientists should prioritize promotion of science over promotion of the scientist. The presupposition of this imperative is a concern that promotion of one's public image distracts from or discredits the message about science conveyed to the public. Yet, this may be a difficult objective to achieve because the line between promoting science and risking accusations of self-promotion is narrow.

Second, scientists emphasize the need for celebrity scientists to understand the public while emphasizing public understanding of science (Lévy-Leblond, 1992). This imperative is tied to perceptions of which audiences celebrity scientists should target and the style of engagement. With respect to audiences, scientists underscore the need for celebrity scientists to move beyond groups for whom public engagement simply represents "preaching to the choir" and away from ideological extremes that are perceived as alienating and antagonistic. This emphasis mirrors other calls from major scientific societies such as the American Association for the Advancement of Science (AAAS), whose former CEO Alan Leshner (2006) believed public engagement "at a minimum should bring scientists into closer proximity with their fellow citizens, which in turn should give each group a far better understanding and greater empathy for the perspective of the other" (p. B20). A challenge of this approach is that some groups in the public do not trust scientists (Gauchat, 2012), while scientists themselves often maintain negative views of the public (Burchell, 2007; Ecklund, 2010; Young and Matthews, 2007). According to the scientists studied here, a way 
to mitigate such a challenge is to understand the perspectives of the public, the values that inform these perspectives and areas where dialogue and social exchange are possible. To be sure, diverse publics are intelligent enough to make their own judgments about science and scientists, but for those who are interested in a more nuanced perspective than can be offered by specific celebrity scientists, dialogue and social exchange between scientists and non-scientist publics could be a valuable mechanism for change. Implicit in these narratives of understanding the public and fostering dialogue is a view that even in a socially contentious debate, scientists can promote public understanding of science by focusing on areas where scientists and skeptical groups can agree.

Some scientists we studied have the assumption that the goal of celebrity scientists ought to be to foster change or dialogue within socially contentious debates. Not all of the scientists we interviewed agree with this objective. Some nonreligious scientists view the role of the celebrity scientist as a provocateur. From this perspective, celebrity scientists have an imperative to assert the cultural authority of science by using their visibility as a "bully pulpit" from which a position on a contentious issue can be vocalized and perpetuated.

The imperatives described by the scientists we interviewed could just as easily be applied to other socially contentious public debates involving scientists and the public, such as climate change, genetically modified organisms, embryonic stem cell research, and human reproductive genetic technologies. In considering the broader applicability of our findings, it is worth noting that Fahy and Lewenstein's (2014) call for research on the implications of celebrity science for science communication - and the practice of science more broadly — assumes that the presence of celebrity scientists in the public sphere holds behavioral implications. Only one scientist that we interviewed implied that Dawkins' involvement actually influenced his practice of science communication. It seems more likely that celebrity scientists, particularly in areas of controversy, provoke scientists to embrace or affirm normative views about how science should be communicated rather than influencing communication or other behaviors. It is possible that in areas that involve greater connection to policy than public debates surrounding science and religion, celebrity scientists could wield more behavioral influence over other scientists, such as provoking their involvement in government decisions about science and technology. Yet, while celebrity engagement can be a part of science policy by promoting meaningful dialogue about contentious issues, one must be careful not to over-promise what such engagement may deliver given the complicated nature of science governance (Stilgoe et al., 2014).

Those who study the public understanding of science have little choice but to pay attention to the role of celebrity scientists because of the increasing integration of science in popular culture as well as the influence that celebrity scientists can wield over public discourse about science and society. One fruitful path forward might involve identifying connections between this nascent literature and core themes related to public understanding of science. This study points to the value in better understanding the relationship between science communication and scientists' understanding of the public. It would also be valuable to determine whether the rise of a "science communication industry" - with the increasing emphasis on researchers in the United Kingdom to engage publics and new career paths in this area-is eclipsing the importance of and focus on celebrity scientists.

Research on transnational dimensions of science popularization are also underexplored (Daum, 2009). Our study was not designed to directly examine how scientists around the world understand Dawkins, but the minimal nature of narratives from scientists located outside of the United Kingdom and the abundance and substance of discourse from scientists within it suggest that concerns about Dawkins' representation of science and religion are specific to British scientists. It could be that scientists outside of the United Kingdom lack interest in how Dawkins engages the public because he is not seen as much as a representative of national scientific communities outside 
the United Kingdom. Future research would profit from direct analyses of scientists in popular culture to determine how perceptions vary across global contexts.

By examining only those scientists who brought Dawkins up in interviews, this analysis is unable to capture how other scientists view his role in science communication. Future research should assess the salience of celebrity scientists to a broad spectrum of scientists, which would offer an important step toward avoiding giving more significance to celebrities than perhaps they deserve.

\section{Funding}

Data collection for this study was funded by the Templeton World Charity Foundation; Elaine Howard Ecklund, PI; and Kirstin R.W. Matthews and Steven W. Lewis, Co-PIs (grant no. 0033/AB14).

\section{Notes}

1. UK_03_BIO

2. UK_24_PHYS

3. UK07 $\overline{\mathrm{BIO}}$

4. UK13 BIO

5. UK08_BIO

6. UK02_BIO

7. UK04_PHYS

8. UK20_PHYS

9. UK22_PHYS

10. UK53_PHYS

11. UK46_BIO

12. UK13_BIO

13. UK29-PHYS

14. UK06 BIO

15. UK04_PHYS

16. UK12 $\mathrm{BIO}$

17. UK13_BIO, UK63_BIO

18. UK104_BIO

19. UK31_PHYS

20. UK63_BIO

21. UK $10 \overline{8}$ BIO

22. UK34 $\overline{\mathrm{B} I O}$

\section{References}

Baker J (2012) Public perceptions of incompatibility between "science and religion." Public Understanding of Science 21: 340-353.

Bauer M, Allum N and Miller S (2007) What can we learn from 25 years of PUS survey research? Liberating and expanding the agenda. Public Understanding of Science 16: 79-95.

Brossard D and Nisbet M (2007) Deference to scientific authority among a low information public. International Journal of Public Opinion Research 19: 24-52.

Browne J (2003) Charles Darwin as a celebrity. Science in Context 16: 175-194.

Burchell K (2007) Empiricist selves and contingent "others": The performative function of the discourse of scientists working in conditions of controversy. Public Understanding of Science 16: 145-162.

Collins F (2006) The Language of God: A Scientist Presents Evidence for Belief. New York, NY: Free Press.

Curry A (2009) Creationist beliefs persist in Europe. Science 323(5918): 1159.

Cyranoski D (2009) Hong Kong evolution curriculum row. Nature 457: 1067. 
Daum AW (2009) Varieties of popular science and the transformations of public knowledge: Some historical reflections. Isis 100: 319-332.

Dawkins R ([1976] 1989) The Selfish Gene. Oxford; New York, NY: Oxford University Press.

Dawkins R (1986) The Blind Watchmaker. Harlow: Longman Scientific \& Technical.

Dawkins R (2006) The God Delusion. Boston, MA: Houghton Mifflin Co.

Ecklund E (2010) Science vs. Religion: What Scientists Really Think. New York, NY: Oxford University Press.

Ecklund E and Park J (2009) Conflict between religion and science among academic scientists? Journal for the Scientific Study of Religion 48: 276-292.

Ecklund E and Scheitle C (2007) Religion among academic scientists: Distinctions, disciplines, and demographics. Social Problems 54: 289-307.

Ecklund E, James S and Lincoln A (2012) How academic biologists and physicists view science outreach. PLOS ONE 7: e36240.

Ecklund E, Johnson DR, Scheitle CP, Matthews KRW and Lewis SW (2016) Religion among scientists in international context: A new study of scientists in eight regions. Socius. Epub ahead of print 1 September. DOI: $10.1177 / 2378023116664353$.

Elsdon-Baker F (2009) The Selfish Genius: How Richard Dawkins Rewrote Darwin's Legacy. London: Icon Books.

Elsdon-Baker F (2015) Creating creationists: The influence of "issues framing" on our understanding of public perceptions of clash narratives between evolutionary science and belief. Public Understanding of Science 24(4): 422-439.

Evans J (2011) Epistemological and moral conflict between science and religion. Journal for the Scientific Study of Religion 50: 707-727.

Fahy D (2015) The New Celebrity Scientists: Out of the Lab and into the Limelight. Lanham, MD: Rowman \& Littlefield.

Fahy D and Lewenstein B (2014) Scientists in popular culture: The making of celebrities. In: Bucchi M and Trench B (eds) Routledge Handbook of Public Communication of Science and Technology. London: Routledge, pp. 83-96.

Gauchat G (2012) Politicization of science in the public sphere: A study of public trust in the United States, 1974 to 2010. American Sociological Review 77: 167-187.

Giberson K and Artigas M (2007) Oracles of Science: Celebrity Scientists versus God and Religion. New York, NY: Oxford University Press.

Goodell R (1977) The visible scientists. The Sciences 17: 6-9.

Goodell R (1985) Problems with the press: Who's responsible? BioScience 35: 151-157.

Gould S (1998) Non-overlapping magisterial. In: Gould S (ed.) Leonardo's Mountain of Clams the Diet of Worms. New York, NY: Harmony Books, pp. 269-284.

Ho S, Brossard D and Scheufele D (2008) Effects of value predispositions, mass media use, and knowledge on public attitudes toward embryonic stem cell research. International Journal of Public Opinion Research 20: 171-192.

Jayaraman K (2001) Angry researchers pour scorn on astrology classes. Nature 411: 227.

Johnson DR, Ecklund E and Lincoln A (2014) Narratives of science outreach in elite contexts of academic science. Science Communication 36: 81-105.

Johnson DR, Scheitle C and Ecklund E (2016) Conservative Protestantism and anti-evolution curricular challenges across states. Social Science Quarterly. Epub ahead of print 12 April. DOI: 10.1111/ssqu.12267.

Kahan D, Jenkins-Smith H and Braman D (2011) Cultural cognition of scientific consensus. Journal of Risk Research 14: 147-174.

Leshner A (2006) Science and public engagement. The Chronicle Review 53: B20.

Lévy-Leblond J (1992) About misunderstandings about misunderstandings. Public Understanding of Science 1: $17-21$.

McComas K and Besley J (2011) Fairness and nanotechnology concern. Risk Analysis 31: 1749-1761.

Mazur A (1985) Bias in risk-benefit analysis. Technology in Society 7: 25-30. 
Merton R (1973) The Sociology of Science: Theoretical and Empirical Investigations. Chicago, IL: University of Chicago Press.

Mitroff I (1974) Norms and counter-norms in a select group of the Apollo Moon Scientists: A case study of the ambivalence of scientists. American Sociological Review 39: 579-595.

Numbers R (2006) The Creationists: From Scientific Creationism to Intelligent Design. Cambridge, MA: Harvard University Press.

Peters H (2014) Scientists as public experts: Expectations and responsibilities. In: Bucchi M and Trench B (eds) Routledge Handbook of Public Communication of Science and Technology. London: Routledge, pp. $70-82$.

Scheitle C (2011) US college students' perceptions of religion and science: Conflict, collaboration, or independence? A research note. Journal for the Scientific Study of Religion 50: 175-186.

Scheitle C and Ecklund EH (2015) The influence of science popularizers on the public's view of religion and science: An experimental assessment. Public Understanding of Science. Epub ahead of print 8 June. DOI: $10.1177 / 0963662515588432$.

Stilgoe J, Lock S and Wilson J (2014) Why should we promote public engagement with science? Public Understanding of Science 23: 4-15.

Strauss A and Corbin J (1990) Basics of Qualitative Research. Newbury Park, CA: SAGE.

Voas D and Crockett A (2005) Religion on Britain: Neither believing nor belonging. Sociology 39: 11-28.

Weir T (2014) Secularism and Religion in Nineteenth-Century Germany. Cambridge: Cambridge University Press.

Young N and Matthews R (2007) Experts' understanding of the public: Knowledge control in a risk controversy. Public Understanding of Science 16: 123-144.

\section{Author biographies}

David R. Johnson is an assistant professor of Higher Education in the College of Education at the University of Nevada, Reno. His research examines the implications of changing social organization of science for stratification and inequality in the academic profession and appears in journals such as Science Technology and Human Values, Science Communication, and The Journal of Higher Education.

Elaine Howard Ecklund is the Herbert S. Autrey chair in Social Sciences and professor of Sociology at Rice University. She is the author, most recently, of Failing Families, Failing Science: Work-Family Conflict in Academic Science (NYU Press, 2016) and Science vs. Religion: What Scientists Really Think (Oxford University Press, 2010).

Di $\mathrm{Di}$ is a doctoral candidate in the Sociology Department at Rice University. Her research interests include gender, immigration, religion, and science ethics, and her work appears in journals such as Science and Engineering Ethics and Journal of Religion \& Society.

Kirstin R.W. Matthews, PhD, is a fellow in Science and Technology Policy at Rice University's Baker Institute for Public Policy and a lecturer in the Wiess School of Natural Sciences. Her research focuses on the intersection between traditional biomedical research and development funding and international scientific collaboration. 